p-ISSN 1693-1246

e-ISSN 2355-3812

June 2020
Jurnal Pendidikan Fisika Indonesia 16 (1) (2020) 1-8

DOI: 10.15294/jpfi.v16i1.23096
$\underbrace{\Phi}_{\text {http://journal.unnes.ac.id/njulindex.php/jpfi }}$

\title{
Relationship Between Behavior of Learning and Student Achievement in Physics Subject
}

\author{
S. A. Azhary ${ }^{1}$, Supahar ${ }^{2}$, Kuswanto ${ }^{3 *}$, M. Ikhlas ${ }^{4}$, I. P. Devi ${ }^{5}$ \\ 1,2Postgraduate Science Education, Universitas Negeri Yogyakarta, Indonesia \\ ${ }^{3,4}$ College of Education, Central Luzon State University, Philippines \\ ${ }^{5}$ SMAN 5 Tebo, Indonesia
}

Received: 1 January 2020. Accepted: 30 March 2020. Published: 30 June 2020

\begin{abstract}
Behavioral problems become special attention to learning. Some teachers confronted with a variety of student behaviors and varied learning outcomes. This research was aimed to determine the relationship between learning outcomes and student learning behavior with ranking score. A total of 91 of 10 th-grade students with three different classes became respondents. The research was used Mixed methods with the sequential explanatory approach. Quantitative data were obtained by giving multiple-choice questions. The interview method was used to collect qualitative data. Kruskal Wallis test was used to analyze quantitative data and the interview transcript analyzed by the keyword of student behavior in learning physics. The results show that behavior while learning is very significant towards student learning outcomes. Interview findings show that student behavior during the learning process could affect learning outcomes.
\end{abstract}

Keywords: Behaviour; Physics Subject; Student Achievement

\section{INTRODUCTION}

The learning process is the process of developing the potential to form better life patterns. The process of learning and teaching is a process that requires the role of a teacher and students. Each student has the same opportunity to gain knowledge. It means teachers must accept the diversity of students in their class. In addition, it is important for students to use their learning style abilities during the learning process, whereas the teacher should use many methods of teaching (Richman, Haines, \& Fello, 2011) and communicating collaboratively during the learning process (Agyekum, 2019). Teachers must be creative to provide teaching materials and learning media (Buabeng, Aquinas Ossei-Anto, \& Ampiah, 2014). Giving fewer academic instructions will make it easier for students to learn (Sutherland \& Oswald, 2005). Effectiveness classroom management or techniques of teaching have a strong and positive influence on student achievement in physics (Adeyemo, 2012).

*Correspondence Address:

Central Luzon State University, Science City of Munoz, Nueva Echija, 3120-Philippines

E-mail: kuswanto@clsu.edu.ph
Physics subject concerning concepts and calculations. Some people said physics is difficult subject, but it depends on individual students in learning the concept, as well as having readiness in learning (Gebauer, 2019). In the concept introduction phase, it is recommended that students build their knowledge and extend it to the stage of applying the topic to other cases (Nuhoğlu \& Yalçın, 2006), although this subject need strong support (Chang, Kohler, Ard, \& Mathis, 2018). It is argued that a physics is not only used to train critical thinking about natural phenomena but also to train student as a lifelong learner and be able to live together (Kuswanto, 2020). To support student learning, teachers can use many teaching methods, and the methods are very dependent on the quality and creativity of teachers in teaching.

A teacher's creativity in choosing teaching methods will affect to student responses to the learning process. The teacher has the ability to teach well, a strong pedagogy (Aksoy, 2019), including choosing strategies and teaching methods (Çalişkan, Selçuk, \& Erol, 2010) and can open perspectives about the concepts possible that are in science correctly (Nuhoğlu \& Yalçın, 2006).

Bringing students in the midst of envi- 
ronmental problems will also provide students with the knowledge, attitudes, and behavioral awareness. Behavioral awareness will be to guide students to be a good learner. The results of the study (Aliman, Budijanto, Sumarmi, \& Astina, 2019) have theoretical implications for agreeing that knowledge is the basis of forming attitudes and attitudes that can influence human behavior. In addition, the ability of humans to solve problems is a holistic representation of humans who have good knowledge awareness (Aliman et al., 2019) One effort is to use constructive approaches to teach many difficult complex physical concepts and knowledge in physics (Karakuyu, 2010). Growing an environmentally sensitive attitude begins with good self-control, this can be reflected in positive behavior during the learning process in the classroom and the teacher must try new things so students can learn from nature to learn well so that they can improve student learning outcomes.

Improved learning outcomes can be measured by using an assessment system. Generally, assessment is one of the evaluations conducted at the end of each semester. Evaluation helps the teacher to assess an understanding of student knowledge. Success students if they have good knowledge and behavior. So, students must be tested for understanding scientific concepts, which can be through practice and exchange knowledge by discussing (Ateş \& Eryilmaz, 2011). All evaluation processes aim to increase knowledge and wise behavior towards life.

To provide good learning behavior, it must be supported by a conducive learning atmosphere. Some previous studies discuss the teacher behavior, student behavior has a significant influence on student achievement (Rose \& Medway, 1981). The risk of student failure is students feel alienated and burdened with decreased performance (Baker, 1999). Behavior can affect learning conditions and affect student learning outcomes (McKinney, Mason, Perkerson, \& Clifford, 1975)multiple regression procedures were carried out in which the frequencies of 12 behaviors were used to predict the achievement scores of 90 2nd graders. Ss, with an average IQ of 98.69, were observed for 5 -min periods on each of 4 days during language arts in the fall of the school year and again in the spring. The final multiple $\mathrm{R}$ between fall behavior patterns and fall achievement was .63 , and that between spring behavior patterns and spring achievement was .51. The final mul- tiple $\mathrm{R}$ for predicting spring achievement from fall behavior was .60. Of particular interest was the finding that the predictive value of combinations of discrete behaviors compared favorably to that obtained from IQ tests $(r=.70$. In addition, school climate also influences children's cognitive, social, and psychological development, because it has a large factor in creating comfort in learning and can improve the quality of learning (Haynes, Emmons, \& Ben-Avie, 1997). Many factors affect learning outcomes, including behavioral factors.

Behavioral problems become special attention in learning. Behavior could be a cause and could be a result of learning outcomes. Behavior problems generally become a broad discussion, including the causes of students who have reading problems (Beasley \& Bernadowski, 2019), the success of taking online courses (Morris, Finnegan, \& Wu, 2005). Some teachers are confronted with a variety of student behaviors, and these behaviors can result in varied learning outcomes. Positives behavior in some students may influence by the teacher (Spilles, Hagen, \& Hennemann, 2019). So, students who have distorted learning behaviors and require wise justification behavior by a teacher or psychology/counseling specialist. This research was aimed to determine the relationship between learning outcomes and student learning behavior.

\section{METHOD}

This study uses a mixed method design focus on explanatory research. The respondent of this research were 91 students of $10^{\text {th }}$ grade senior high school who took physics subject, include 34 students from class X, 29 students from class $Y$ and 28 students from class $Z$. Quantitative data were collected from multiple choice question focused on understanding of knowledge on whole physics subject on one semester. From the results of student scores obtained, these scores are ranked. Because students' scores are in the form of ranking, the data is categorized as ordinal data, wherein statistical analysis techniques data that are ordinal must use non-parametric statistics tests (Connolly, 2007). In this study, a non-parametric Kruskal Wallis $\mathrm{H}$-test was used to see the difference in the mean score rank found in those three classes. Furthermore, qualitative data were collected from interview, focused on behavior of learning when studied physics in classroom. The interview transcript analyzed 
by keyword in behavior. The findings of these data are analyzed and compared with previous research and reviewed from several theories of behavior.

\section{RESULT AND DISCUSSION}

Student academic learning outcomes show varied values for the three classes analyzed. Classes are named with the $X, Y$ and $Z$. The results of statistical analysis, it was found that class $X$ had the lowest average score compare with class $Y$ and $Z$. The average score in class $Y$ has the highest number between the two other classes. Statistical results are shown in the Table 1.

Table 1. Descriptive statistics of student physics learning outcomes.

\begin{tabular}{lcccc}
\hline Group & N & $\begin{array}{c}\text { Mini- } \\
\text { mum } \\
\text { rank } \\
\text { Scores }\end{array}$ & $\begin{array}{c}\text { Maxi- } \\
\text { mum } \\
\text { rank } \\
\text { Scores }\end{array}$ & $\begin{array}{c}\text { Classical } \\
\text { Mean } \\
\text { rank } \\
\text { Scores }\end{array}$ \\
\hline Class X & 34 & 57.5 & 85.0 & 69.191 \\
Class Y & 29 & 65.0 & 100.0 & 77.328 \\
Class Z & 28 & 65.0 & 87.5 & 77.143 \\
Valid N & 28 & & & \\
(listwise) & & & & \\
\hline
\end{tabular}

The results of the analysis by using Kruskal Wallis were coducted to determine the significance of the learning outcomes of the three classes. The physics earning outcomes show significant differences. This is seen from the Asymp value. Sig $=0,000$, and the data rank of the three classes can be seen in the Table 2 and Table 3.

Table 2. Mean Ranks of the Kruskal-Wallis Test on student learning outcomes of physics subjects.

\begin{tabular}{lcc}
\hline Group & N & Mean Rank \\
\hline Class X & 34 & 28.97 \\
Class Y & 29 & 55.52 \\
Class Z & 28 & 56.82 \\
Total & 91 & \\
\hline
\end{tabular}

The mean rank for students who learned physics to class $X$, class $Y$, and class $Z$ is 28.97 , 55.52 and 56.82 respectively. The Chi-Square statistics was 22.811 and $p<0.001(p=0.000)$. It means that the achievement of physics in different class has significant differences.
Table 3. Kruskal Wallis Test and Grouping Variable Test

\begin{tabular}{lc}
\hline & S Physics \\
\hline Chi-Square & 22.811 \\
Df & 2 \\
Asymp. Sig. & .000 \\
\hline a. Kruskal Wallis Test \\
b. Grouping Variable: Group
\end{tabular}

From the calculation results obtained that between classes $X$ and $Y, X$ and $Z$ have $a$ Different in different significance $(p<0.001 ; p=$ 0.000 ). But for $Y$ and $Z$ there is no significant difference ( $p>0.5 ; p=0.809$ ). Furthermore, the average scores for the three classes are presented in Figure 1.

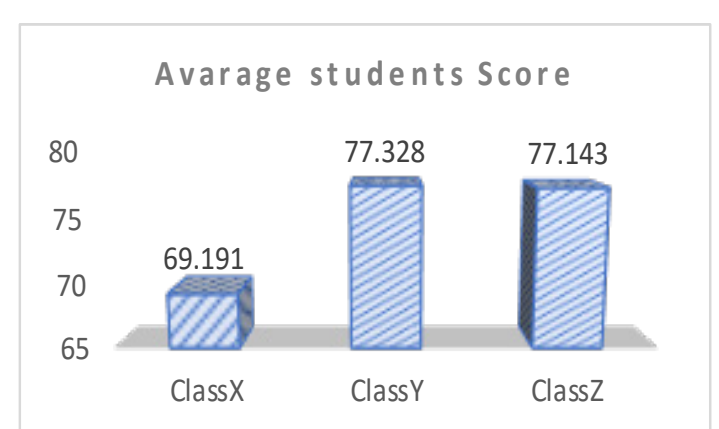

Figure 1. Bar diagram of the students' physics scores

From Figure 1 it can be concluded that the average values of classes $Y$ and $Z$ are not much different (77) but in class $X$ only 69 . To explain this phenomenon, it can be seen from the teacher's confirmation about class X. Obtained an implied statement that class $X$ students have low grades because physics is not the main subject (in social studies, physics is not a priority). The summarizes the results of the interview as Table 1.

What distinguishes the three classes is learning motivation which has an impact on student learning behavior. As explained by the teacher "students who joke when learning to tend to be difficult to accept lessons" can be influenced by motivation. Motivation greatly influences the learning process and results in student learning outcomes (Ziegler \& Heller, 2000). This is the case of class $X$ because in this class physics is not the main subject, it is likely that students do not have high motivation to learn so that the average value of students tends to below. Research by Morris et al (2005) explains that failure begins with a lack of 
motivation because they feel less useful. This needs to be stressed on the importance of physics and linking it with everyday life including in problem-based (Selçuk, Çalişkan, \& Şahin, 2013) which aims to increase the usefulness and increase student motivation. The statement as summarized in the study states that intrinsic motivation, extrinsic motivation and learning behavior together affect student achievement (Tokan \& Imakulata, 2019). It show that the academic performance of science students is closely related to the components of motivation, self-efficacy and intrinsic value (Peng, 2012). For science students, their involvement in the motivational component is closely related to their performance on the exam.

Other empirical studies of the influence of student learning behavior in class and peer disorders. As can be seen from the results of the teacher's interview, about behaving "joking with classmates while studying" this can affect the learning atmosphere. Research by Blank and Shavit (2016) explained that disruptive or aggressive behavior in the classroom influences the pattern of learning behavior in class that can inhibit learning. This is inseparable from the influence of classroom management (Larmer, Baker, \& Gentry, 2016). The physics teachers must be understand the characteristics of students (Korur \& Eryilmaz, 2012); makes every concept of physics more important (Selçuk, 2010); and explaining the use of real problem-based learning (Engels, Miller, Squires, Jennewein, \& Eitel, 2017). Improvement of value learning, especially self-concepts friendly and creates a conducive classroom environment that makes learning physics more practical (Dupe, 2013) can be done by creating group discussions and evaluations between students (Handayani, Genisa, \& Triyanto, 2019).
Behavioral problems are a matter of perspective. These are not only influenced by teacher behavior but also influenced by student behavior. In the classroom disruptions damage the quality of teaching and learning, and that can be a source of tension for teachers and students (Eckstein, 2019)and they can be a source of strain for both teachers and students. Some studies indicate, however, that not everyone involved gets equally disturbed by the same occurrences. Altogether, there is still little solid knowledge about the teachers' and the students' subjective perception of disturbance. Moreover, rater effects may have confounded the findings available. Addressing these desiderata, the SUGUS study investigates two elements of classroom disturbances within an interactionist framework: the incidence of deviant behaviour shown by particular target students, and the intensity of disturbance as subjectively perceived by teachers, by classmates, and by the targets themselves. For this purpose, we conducted a questionnaire survey among 85 primary-school class teachers and 1412 students. The data were analysed by means of a two-level correlated trait - correlated method minus one [CT-C(M-1. Behaviors that interfere with the learning process can interfere with teaching activities and have an impact on the delivery of teaching. Characteristics of students hampered in learning, attention distracted learning, the destruction of learning motivation, and lack of desire to learn. In the learning process disorders are generally influenced by; lack of motivation, hopelessness to learning, hopelessness to be successful, lack of readiness to learn, and prejudice about physics (Bayar \& Kerns, 2015). In this case the student needs guidance counseling or treatment if they have behavior disorders (Lassen, Steele, \& Sailor,

Table 3. Results of interview resumes from class teacher confirmation

\begin{tabular}{|c|c|c|}
\hline Title of Class & Description & $\begin{array}{l}\text { Behavior of students who get high } \\
\text { grades }\end{array}$ \\
\hline Class $\mathrm{X}$ & $\begin{array}{l}\text { Students sometimes joke and seem } \\
\text { less serious, because of the social } \\
\text { science class. But there are some } \\
\text { children who are serious in the lesson. } \\
\text { Students sometimes joke and it's hard to } \\
\text { understand learning }\end{array}$ & $\begin{array}{l}\text { Students who have the highest } \\
\text { grades are enthusiastic in learning. }\end{array}$ \\
\hline Class Y & $\begin{array}{l}\text { Students have an enthusiasm for } \\
\text { learning, although sometimes there are } \\
\text { some children who joke. Some students } \\
\text { sometimes make noise. }\end{array}$ & $\begin{array}{l}\text { And students who have the highest } \\
\text { grades are silent and passive in } \\
\text { class. }\end{array}$ \\
\hline Class Z & $\begin{array}{l}\text { This class tends to be serious and } \\
\text { relaxed. There are students who enjoy } \\
\text { talking to classmates. }\end{array}$ & $\begin{array}{l}\text { Students who have the highest } \\
\text { grades are serious in learning but not } \\
\text { so prominent in class }\end{array}$ \\
\hline
\end{tabular}


2006)

Changes and handling of student behavior in learning must be addressed appropriately so that changes in student behavior are measured and monitored. Research by Lassen et al. (2006) suggests that it is important to conduct special notes for teachers in monitoring student behavior (such as based on location, based on the problematic behavior, based on ethical behavior). Thus, if the behavioral problem is not resolved, the impact will be a continuous decline in learning outcomes. Moreover, if physics learning outcomes are low, how can they anticipate the development of knowledge and technology? Meanwhile according to Wambugu \& Changeiywo (2008) knowledge about science and technology is a requirement in all countries and all people globally due to the many challenges faced.

Success and failure in the context of learning are relative. But the learning outcomes perspective that meets the standards is determined by the teacher's agreement in determining the mastery of learning by looking at students' abilities and learning targets. The success of student achievement can be influenced by effort in maximizing one's ability to learn, focus on goals and behave as good learners (Ramshe, Ghazanfari, \& Ghonsooly, 2019). The efforts made to improve the quality of learning can be achieved by growing meaningful patterns of learning behavior. The teacher also confirmed that 'students who have the highest grades are serious in learning'. However, changing behavior patterns requires high self-efficacy and these changes are expected to have a positive impact (Mitchell, McMillan, \& Rabbani, 2019).

Many of the cases of deviations in learning behavior found in teenagers (Crosnoe, Johnson, \& Elder, 2004). It happened in class Z where students who enjoy talking to my classmates usually have problems in the family, friends, and the influence of the environment and even watching or online media will affect their behavior even when studying in class (Ayu, Wibowo, \& Sofiana, 2019). Adolescent students are very vulnerable to the risk, either in the community or in the classroom. Learning behavior in the classroom and at home greatly different influences learning outcomes and the quality of student work outcomes (Peng, 2012). According to Sutherland \& Oswald (2005), the environment is a major factor in the development of behavior.

The activities that can be done to imp- rove behavior patterns and learning outcomes, we can see the results of teacher interviews that explain the behavior patterns of students who get high grades. The interview results show that; 'Students who have the highest grades are enthusiastic in learning'; 'students who have the highest grades are silent and passive in class'; and 'students who have the highest grades are serious in learning but are not so prominent in the class'. Of the three statements, the teacher leads to seriousness in learning, ignoring disturbances that exist in the classroom, focus on what is conveyed by the teacher. Classroom disturbances and obstacles are inevitable, but the ability of students to control their behavior becomes an important point for success in learning. This correlates with Pardos \& Horodyskyj (2019) and Eineder \& Bishop (1997) that a positive behavior, organized learning patterns and having disciplined patterns to accept learning in an orderly manner are a requirement to be successful learners.

In addition, some experts claim that the teacher can be a factor for student learning outcomes. Teachers visit to the homes of students who have problems (Ilhan, Ozfidan, \& Yilmaz, 2019). Adeyemo (2010) suggested that teacher should give the time for student to be participation in extracurricular activities in school.

To support student learning, teachers can use many teaching methods, modify the learning environment, especially at the low school level (Carr \& Boat, 2019). Social norms of students in certain classes can influence the way they behave (Blank \& Shavit, 2016). Same case in the $X$ class they tend not to be serious in learning because of their environment. Physics not only about principles and calculations but also develops ways to improve thinking and reasoning to the maximum. Making simple tools to aid will help students understand the thinking about physics theory (Ateş \& Eryilmaz, 2011). Wisdom knowledge material to make lessons more effective (Oladejo, Olosunde, Ojebisi, \& Isola, 2011). The effect of learning will be improved of skills with higher-level questions (Stronge, Ward, Tucker, \& Hindman, 2007). The last point, learning behavior in physics can assist teachers to know whether students are focused, understand concepts, know procedural instructions and measure appropriate learning outcomes. Student learning can be improved by providing guidance and learning instructions after analyzing student learning behavior. But, high or low grades are not a consideration, students can think and behave scientifical- 
ly correctly (Purba \& Hwang, 2018).

\section{CONCLUSION}

This research answered a purpose of this research; to determine the relationship between learning outcomes and student learning behavior. The conclusion is student behavior during the learning process can affect learning outcomes. High and low learning outcomes can be caused by many factors, among them; motivation, teacher, student learning intention. The researcher suggests using many learning methods when pursuing because it can summarize each student's learning style. Furthermore, we urge to increase awareness for teachers to condition a comfortable learning process during the learning process. Because the atmosphere of learning can have an impact on the comfort and focus of student learning processes

\section{REFERENCES}

Adeyemo, S. A. (2010). The relationship between students participation in school based extracurricular activities and their achievement in physics. International Journal of Science and Technology Education Research, 1(6), 111117. Retrieved from http://www.academicjournals.org/JSTER

Adeyemo, S. A. (2012). The relationship between effective classroom management and students ' academic achievement. European Journal of Educational Studies, 4(3), 367-381.

Agyekum, S. (2019). Teacher-Student Relationships: The Impact on High School Students. Journal of Education and Practice, 10(14), 121-122. https://doi.org/10.7176/jep/10-14-15

Aksoy, G. (2019). Exploration of Pre-Service Science Teachers' Perceptions towards Secondary School Science Curriculum. International Journal of Contemporary Educational Research, 6(1), 11-28. https://doi.org/https:// doi.org/10.33200/ijcer.543360

Aliman, M., Budijanto, Sumarmi, \& Astina, I. K. (2019). Improving environmental awareness of high school students' in Malang city through earthcomm learning in the geography class. International Journal of Instruction, 12(4), 79-94. https://doi.org/10.29333/ iji.2019.1246a

Ateş, Ö., \& Eryilmaz, A. (2011). Effectiveness of hands-on and minds-on activities on students' achievement and attitudes towards physics. Asia-Pacific Forum on Science Learning and Teaching, 12(1), 1-22.

Ayu, S. M., Wibowo, M., \& Sofiana, L. (2019). Risky teenager behavior in a vocational high school. International Journal of Evaluation and Research in Education, 8(3), 470-475. https://doi.org/10.11591/ijere.v8i3.20241

Baker, J. A. (1999). Teacher-student interaction in urban at-risk classrooms: Differential behavior, relationship quality, and student satisfaction with school. Elementary School Journal, 100(1), 57-70. https://doi. org/10.1086/461943

Bayar, A., \& Kerns, J. H. (2015). Undesired Behaviors Faced in Classroom by Physics Teachers in High Schools. Online Submission, 7(1), 37-45.

Beasley, K. T., \& Bernadowski, C. (2019). An examination of reading specialist candidates' knowledge and self-efficacy in behavior and classroom management: An instrumental case study. Education Sciences, 9(76), 1-9. https://doi.org/10.3390/educsci9020076

Blank, C., \& Shavit, Y. (2016). The Association Between Student Reports of Classmates' Disruptive Behavior and Student Achievement. AERA Open, 2(3), 1-17. https://doi. org/10.1177/2332858416653921

Buabeng, I., Aquinas Ossei-Anto, T., \& Ampiah, J. G. (2014). An Investigation into Physics Teaching in Senior High Schools. World Journal of Education, 4(5), 40-50. https://doi. org/10.5430/wje.v4n5p40

Çalişkan, S., Selçuk, G. S., \& Erol, M. (2010). Instruction of problem solving strategies: Effects on physics achievement and selfefficacy beliefs. Journal of Baltic Science Education, 9(1), 20-34.

Carr, V., \& Boat, M. (2019). "You Say Praise, I Say Encouragement" - Negotiating Positive Behavior Support in a Constructivist Preschool. Athens Journal of Education, 6(3), 171-188. https://doi.org/10.30958/aje.6-3-1

Chang, H. Y., Kohler, J. N., Ard, J. E., \& Mathis, C. (2018). Examining reasons behind high school students' decisions to enroll in physics courses. Universal Journal of Educational Research, 6(11), 2492-2497. https://doi. org/10.13189/ujer.2018.061113

Connolly, P. (2007). Quantitative data analysis in education: A critical introduction using SPSS. Routledge

Crosnoe, R., Johnson, M. K., \& Elder, G. H. (2004). Intergenerational Bonding in School: The Behavioral and Contextual Correlates of Student-Teacher Relationships. Sociology of Education, 77(1), 60-81. https://doi. org/10.1177/003804070407700103

Dupe, O. B. (2013). Predicting Students' Achievement in Physics using Academic Self Concept and Locus of Control Scale Scores. International J. Soc. Sci. \& Education, 3(4), 1149-1155. Retrieved from http://www.ijsse. com/sites/default/files/issues/2013/v3i4/papers/Paper-30.pdf

Eckstein, B. (2019). Production and perception of 
classroom disturbances - A new approach to investigating the perspectives of teachers and students. Frontline Learning Research, 7(2), 1-22. https://doi.org/10.14786/ flr.v7i2.411

Eineder, D. V., \& Bishop, H. L. (1997). Blockscheduling the high school: The effects on achievement, behavior, and student-teacher relationships. NASSP Bulletin, 81(589), 45-54. https://doi. org/10.1177/019263659708158907

Engels, M., Miller, B., Squires, A., Jennewein, J. S., \& Eitel, K. (2017). The Confluence Approach: Developing scientific literacy through projectbased learning and place-based education in the context of NGSS. Electronic Journal of Science Education, 23(3), 33-58.

Gebauer, R. (2019). The Critical Nature of Intentionality When Supporting Academically Underprepared Students Through Learning Communities. Learning Communities Research and Practice, 7(1), 7. Retrieved from https:// washingtoncenter.evergreen.edu/lcrpjournal/ vol7/iss $1 / 3$

Handayani, R. D., Genisa, M. U., \& Triyanto. (2019). Empowering physics students' performance in a group discussion through two types of peer assessment. International Journal of Instruction, 12(1), 655-668. https://doi. org/10.29333/iji.2019.12142a

Haynes, N. M., Emmons, C., \& Ben-Avie, M. (1997). School Climate as a Factor in Student Adjustment and Achievement. Journal of Educational and Psychological Consultation, 8(3), 321-329. https://doi.org/10.1207/ s1532768xjepc0803_4

Ilhan, F., Ozfidan, B., \& Yilmaz, S. (2019). Home visit effectiveness on students' classroom behavior and academic achievement. Journal of Social Studies Education Research, 10(1), 61-80.

Karakuyu, Y. (2010). The effect of concept mapping on attitude and achievement in a physics course. International Journal of Physical Sciences, 5(6), 724-737.

Korur, F., \& Eryilmaz, A. (2012). Teachers' and students' perceptions of effective physics teacher characteristics. Egitim Arastirmalari - Eurasian Journal of Educational Research, (46), 101-120.

Kuswanto. (2020). Where is the Direction of Physics Education? Jurnal PIJAR MIPA, 15(1), 5964. https://doi.org/http://dx.doi.org/10.29303/ jpm.v15i1.1226 ISSN

Larmer, W., Baker, C., \& Gentry, J. (2016). a Model for Online Support in Classroom Management: Perceptions of Beginning Teachers. Administrative Issues Journal: Education, Practice, and Research, 6(1), 22-37. https:// doi.org/10.5929/2016.6.1.3

Lassen, S. R., Steele, M. M., \& Sailor, W. (2006). The relationship of school-wide positive behavior support to academic achievement in AN Urban middle school. Psychology in the Schools, 43(6), 701-712. https://doi. org/10.1002/pits.20177

McKinney, J. D., Mason, J., Perkerson, K., \& Clifford, M. (1975). Relationship between classroom behavior and academic achievement. Journal of Educational Psychology, 67(2), 198-203. https://doi.org/10.1037/h0077012

Mitchell, K. M., McMillan, D. E., \& Rabbani, R. (2019). An Exploration of Writing Self-Efficacy and Writing Self-Regulatory Behaviours in Undergraduate Writing. The Canadian Journal for the Scholarship of Teaching and Learning, 10(2), 25. https://doi.org/10.5206/ cjsotl-rcacea.2019.2.8175

Morris, L. V., Finnegan, C., \& Wu, S. S. (2005). Tracking student behavior, persistence, and achievement in online courses. Internet and Higher Education, 8(3), 221-231. https://doi. org/10.1016/j.ineduc.2005.06.009

Nuhoğlu, H., \& Yalçın, N. (2006). The effectiveness of the learning cycle model to increase students' achievement in the physics laboratory. Journal of Turkish Science Education, 3(2), 28-30. Retrieved from http://www.tused. org/internet/tused/archive/V3/i2/text/tusedv3i2s4.pdf

Oladejo, M. A., Olosunde, G. R., Ojebisi, A. O., \& Isola, O. M. (2011). Instructional Materials and Students 'Academic Achievement in Physics: Some Policy Implications. European Journal of Humanities and Social Sciences Vol., 2(1), 113-126. Retrieved from https://www.researchgate.net/publication/265076250

Pardos, Z. A., \& Horodyskyj, L. (2019). Analysis of student behaviour in habitable worlds using continuous representation visualization. Journal of Learning Analytics, 6(1), 1-15. https://doi.org/10.18608/jla.2019.61.1

Peng, C. (2012). Self-Regulated Learning Behavior of College Students of Science and Their Academic Achievement. Physics Procedia, 33, 1446-1450. https://doi.org/10.1016/j. phpro.2012.05.236

Purba, S. W. D., \& Hwang, W. Y. (2018). Investigation of learning behaviors and achievement of simple pendulum for vocational high school students with Ubiquitous-Physics app. Eurasia Journal of Mathematics, Science and Technology Education, 14(7), 2877-2893. https://doi.org/10.29333/ejmste/90985

Ramshe, M. H., Ghazanfari, M., \& Ghonsooly, B. (2019). The role of personal best goals in EFL learners' behavioural, cognitive, and emotional engagement. International Journal of Instruction, 12(1), 1627-1638. https://doi. org/10.29333/iji.2019.121103a

Richman, L. J., Haines, S., \& Fello, S. (2011). Collaborative Professional Development Focused on Promoting. Science Education International, 30(3), 200-208. https://doi.org/ 
https://doi.org/10.33828/sei.v30.i3.6

Rose, J. S., \& Medway, F. J. (1981). Teacher locus of control, teacher behavior, and student behavior as determinants of student achievement. Journal of Educational Research, 74(6), 375-381. https://doi.org/10.1080/00220671. 1981.10885334

Selçuk, G. S. (2010). The effects of problem-based learning on pre-service teachers' achievement, approaches and attitudes towards learning physics. International Journal of Physical Sciences, 5(6), 711-723.

Selçuk, G. S., Çalişkan, S., \& Şahin, M. (2013). A Comparison of Achievement in ProblemBased, Strategic and Traditional Learning Classes in Physics. In International Journal on New Trends in Education and Their (Vol. 4). Retrieved from www.ijonte.org

Spilles, M., Hagen, T., \& Hennemann, T. (2019). Playing the Good Behavior Game during a Peer-Tutoring Intervention: Effects on Behavior and Reading Fluency of Tutors and Tutees with Behavioral Problems. Insights into Learning Disabilities, 16(1), 59-77.

Stronge, J. H., Ward, T. J., Tucker, P. D., \& Hindman, J. L. (2007). What is the relationship between teacher quality and student achievement? An exploratory study. Journal of Personnel Eval- uation in Education, 20, 165-184. https://doi. org/10.1007/s11092-008-9053-Z

Sutherland, K. S., \& Oswald, D. P. (2005). The relationship between teacher and student behavior in classrooms for students with emotional and behavioral disorders: Transactional processes. Journal of Child and Family Studies, 14(1), 1-14. https://doi.org/10.1007/s10826005-1106-z

Tokan, M. K., \& Imakulata, M. M. (2019). The Effect of Emotional Intelligence and Learning Motivation on Student Achievement. South African Journal of Education, 39(1), 1-8. https:// doi.org/10.2991/icamr-18.2019.94

Wambugu, P. W., \& Changeiywo, J. M. (2008). Effects of mastery learning approach on secondary school students' physics achievement. Eurasia Journal of Mathematics, Science and Technology Education, 4(3), 293-302. https://doi.org/10.12973/ejmste/75352

Ziegler, A., \& Heller, K. A. (2000). Approach and avoidance motivation as predictors of achievement behavior in physics instructions among mildly and highly gifted eighthgrade students. Journal for the Education of the Gifted, 23(4), 343-359. https://doi. org/10.1177/016235320002300402 